\title{
EVALUATION OF OPTIONS FOR ERECTING SMALL HYDROELECTRIC POWER PLANTS ON THE RIVER BYSTRZYCA PÓŁNOCNA
}

\author{
Andrzej Mazur', Antoni Grzywna', Alina Kowalczyk-Juśko', Jarosław Cybulski² \\ 1 Department of Environmental Engineering and Geodesy, University of Life Sciences in Lublin, Leszczyńskiego \\ 7 Str., 20-069 Lublin, Poland, e-mail: amazur70@op.pl \\ 2 HC Concept Sp. z o.o., Rynek Wielki 2 Str., 22-400 Zamość, Poland
}

Received: 2016.08.01 Accepted: 2016.09.26 Published: 2016.11.01

\begin{abstract}
This paper contains an analysis of conditions for erecting small hydroelectric power plants on the selected river in Lublin Region. The analysis covers technical options of the location of the facilities and their energy potential split into theoretical and technical potential. In addition, it refers to the most important legislative acts governing water management, including environmental protection. According to the analysis, the technical potential of small hydroelectric power plants on the river Bystrzyca Północna is about $125.5 \mathrm{~kW}$. Energy production capacity is limited by both hydrological conditions and the necessity to adapt to regulatory framework concerning nature and environment protection, superior functions of watercourses and their situation in agricultural land.
\end{abstract}

Keywords: hydropower engineering, small hydroelectric power plants, energy potential

\section{INTRODUCTION}

The world's water resources are about 1.4 billion $\mathrm{km}^{3}$. Water is required for life and it actually gave rise to life. Man needs it all the time: for household, agricultural, industrial, sanitary, transport, and recreational purposes. The world's water resources are also a huge energy storage that currently accounts for nearly $20 \%$ of global electricity production [Wilgat 1998].

Hydroelectric power plants are most intensely utilized renewable energy source in the world. In 2014 they supplied 3884 TWh of electricity in total, which corresponds to $16.5 \%$ of the world's production of electricity. The capacity of the largest hydroelectric power plants exceeds $10 \mathrm{GW}$. Norway, Democratic Republic of the Congo, Paraguay and Brazil obtain more than $85 \%$ of electricity from hydroelectric power plants. Europe generates $567000 \mathrm{GWh}$ of electricity/year in hydroelectric power plants with a capacity totalling $157 \mathrm{GW}$. Theoretical resources of hydroelectric energy in the world are estimated at $19 \%$ of the total world's production of energy. In 65 world countries hydropower accounts for $50 \%$ of the national production of energy and in 32 - for more than $80 \%$. It is sufficient to add that conventional power plants would need to use 1595 tonnes of coal in order to generate an identical amount of energy [Koch 2002]. Despite in many European countries hydroelectric power engineering developed most intensively many years ago, it has remained an active branch of the energy industry. This is due to both the fact that new hydroelectric power plants are built and older, small hydroelectric power plants (SHP) with a capacity from 0.1 to $10 \mathrm{MW}$ are refurbished and modernized.

The increase in the use of energy from renewable sources, recommended by the European Union and justified for economic and environmental reasons, makes people reach for, among other resources, hydroelectric energy [Jarosiewicz, Toczko 2006; Kamiński and Wójcik-Jackowski 2011; Bełej, Ostrowska 2007]. In Poland the conditions for hydropower engineering development are not very good with regard to 
small downslopes, small amount of rainfall and increased soil permeability [Kułagowski 2001]. The surface water resources in Lublin Region are among the smallest in Poland [Pichla, Jakimiuk 2014]. Poland's theoretical hydropower resources are estimated at about $23 \mathrm{TWh}$ (corresponding to power of $2700 \mathrm{MW}$ ), technically usable resources - at about $12 \mathrm{TWh}$, whereas economic resources at about $8 \mathrm{TWh}$. Theoretically, hydropower could cover about $8 \%$ of the national energy requirement [Gajda 2006, Mikulski 1998]. However, in 2014 hydropower engineering accounted only for $1.4 \%$ of electricity (2.2 TWh) generated in 771 hydroelectric power plants, including 743 SHP, with a total capacity totalling $966 \mathrm{MW}$ [www.ure.pl].

The small degree of utilization of the hydropower potential is not only a matter of technical conditions, but also more often it is connected with the environmental issues caused by the construction and operation of hydroelectric power plants. This paper is a review of the technical options for managing the existing impoundment structures on the selected river as well as environmental conditions and regulatory framework regarding the construction of small hydroelectric power plants, if any, in such locations.

\section{HYDROGRAPHIC CHARACTERISTICS}

The studies were carried out on the river Bystrzyca Północna (in some references called Bystrzyca Duża) - the right-side tributary of the river Tyśmienica on $16^{\text {th }} \mathrm{km}$ of the river course. The basin covers an area of $707 \mathrm{~km}^{2}$ and is situated in the Mazovian Lowland (Small Mazovia). The river, $55.8 \mathrm{~km}$ long, starts near the village of Jedlanka at an altitude of $177 \mathrm{~m}$ above sea level. Its headwaters stream is regulated. The Bystrzyca flows through a valley that is about $1 \mathrm{~km}$ wide, intersected with ditches, and with numerous peat pits. The meandering channel was only partly adjusted by artificial means. Up to the Tyśmienica, the river flows at $2.9 \mathrm{~m}^{3} / \mathrm{s}$, and its average stream slope is $0.78 \%$. The Bystrzyca Północna is a typical lowland river with very small gradients. It is characterised by sandy bottom and considerable shrub cover of the banks, which reduces the rate of water flow (the river is often frozen). Water from the river at some levels is used to fill ponds, which reduces the time of operation of potential power plants. The watershed of the Bystrzyca Północna on a plain with numerous pits is unclear. It is connected, through water gates, with the basins of the rivers Wilga and Krzna. The catchment area is characterized by a dense network of drainage ditches, which contributed to transforming wetlands into grasslands (oncemown semi-natural grassland) [Wilgat 1998, Aktualizacja... 2004].

The analyzed catchment basin is characterized by low natural values and it lacks natural protected areas. The catchment basin is predominantly used for agricultural purposes - mainly grasslands, non-urbanized territory (no cities). The town of Radzyń Podlaski (20 thousand inhabitants) is situated $20 \mathrm{~km}$ away from the mouth of the river.

Table 1 presents the key technical parameters of dams on the river Bystrzyca Północna with impoundment elevation exceeding $0.7 \mathrm{~m}$, according to planning information [Program... 2008], verified in field conditions. The structures are 6 multi-compartment weirs and 2 stop logs. Figure 1 shows their location. In addition, the headwaters have six concrete steps that are up to $0.5 \mathrm{~m}$ tall. With regard to the hydrological conditions, that is water flow above $1 \mathrm{~m}^{3} / \mathrm{s}$, only structures in the depositional zone can be used as locations for erecting small hydroelectric power plants.

Table 1. Technical characteristics of impoundment structures

\begin{tabular}{|c|c|c|c|c|c|c|}
\hline No. & Type of structure & $\mathrm{km}$ & Location & Clearance $[\mathrm{m}]$ & Elevation $[\mathrm{m}]$ & Usage \\
\hline 1 & Weir & $0+450$ & Tchórzew & $2 \times 5$ & 1.60 & retention \\
\hline 2 & Weir & $8+180$ & Borki & $3 \times 5$ & 2.45 & ponds \\
\hline 3 & Weir & $13+380$ & Krasew & $3 \times 4$ & 2.35 & hydration \\
\hline 4 & Weir & $18+230$ & Borowe & $4 \times 2$ & 2.55 & ponds \\
\hline 5 & Weir & $29+060$ & Sobole & $6 \times 2.5$ & 2.47 & hydration \\
\hline 6 & Weir & $33+860$ & Zofibór & $4 \times 2.5$ & 1.51 & hydration \\
\hline 7 & Lock & $45+530$ & Józefów & 4.8 & 1.00 & hydration \\
\hline 8 & Lock & $52+130$ & Celiny & 5.8 & 1.40 & hydration \\
\hline
\end{tabular}




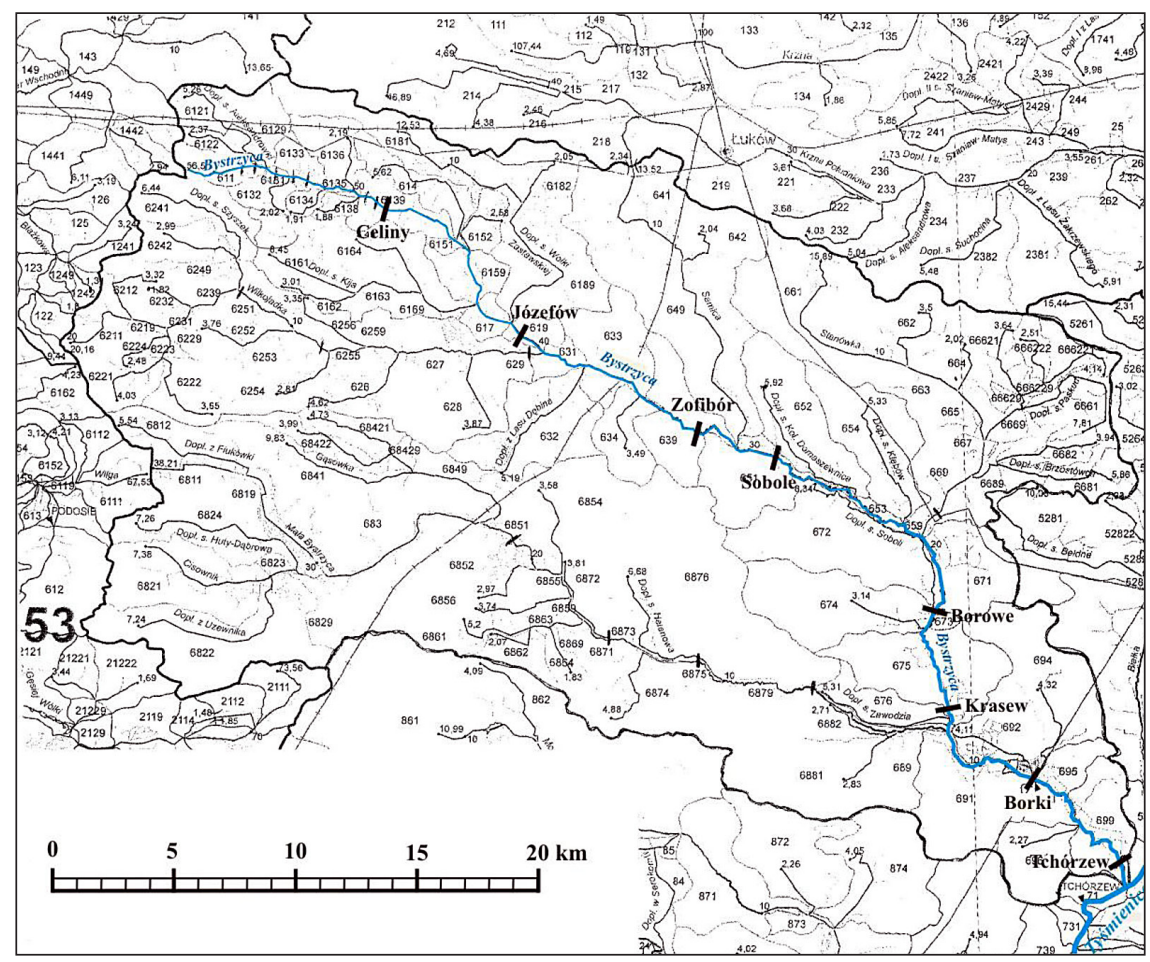

Figure 1. Location of impoundment structures on the river Bystrzyca Północna

\section{ENERGY CHARACTERISTICS}

The energy potential of the analyzed river was calculated by means of the following formula [Karolewski, Ligocki 2004]:

$$
P=\gamma \cdot g \cdot Q \cdot h
$$

where: $P$ - energy potential [W],

$\gamma$ - specific gravity of water, $\gamma=1000 \mathrm{~kg} / \mathrm{m}^{3}$

$g-$ acceleration of gravity, $g=9.81 \mathrm{~m} / \mathrm{s}^{2}$,

$Q$ - flow rate $\left[\mathrm{m}^{3} / \mathrm{s}\right]$,

$h$-slope height [m].

The theoretical capacity of the power plant is calculated based on the mean flow rate across the river and the impoundment elevation upon an assumption that the structure operates all year round. The technical capacity of the power plant was calculated based on the design flow, taking the coefficient of performance into account. The design flow was adopted as $90 \%$ of the mean flow. The power plant performance coefficient ranges from 0.84 to 0.90 , whereas its mean value 0.87 was adopted for calculation purposes. In order to calculate the potential amount of energy that a specific hydropower structure can generate, in addition the actual operating time of the power plant must be taken into consideration. It depends on the location of the structure, its use for other purposes and water flow conditions. The power plant operating time for weirs $1,3,5$ and 6 was assumed as 300 days with regard to their location in a grassland complex, the necessity to maintain the structures and the possible occurrence of ice phenomena. For weirs 2 and 4 a shorter period of time was assumed with regard to the necessity of filling fish ponds [Witkowski et al. 2001].

Table 2 describes the parameters of small hydroelectric power plants that can be erected on the analyzed river.

The energy potential of structure 1 (Tchórzew weir) was managed. In the first half of 2016 a small hydroelectric power plant with a capacity of $49 \mathrm{~kW}$ was built there. It used a screw turbine, also called an Archimedean screw hydro turbine, with a rotor diameter of $2650 \mathrm{~mm}$. The turbine was made along with a flood evacuation system. It consists of turbines mounted without concrete foundations in impoundment structures including a flood evacuation system and the construction of by-pass channels on steel piles with steel walls (Figure 2). Such solutions can reduce the cost of erection by up to $50 \%$. The solution is innovative, relatively inexpensive and has little effect on the environment [WheatonGreen 2016]. A small hydroelectric power plant with a capacity of $50 \mathrm{~kW}$ operates in the village of Borki (structure 2) within the limits of the weir attached to an old watermill (Figure 3). 
Table 2. Hydropower characteristics of the structures

\begin{tabular}{|c|c|c|c|c|c|c|c|}
\hline \multirow{2}{*}{ No. } & \multirow{2}{*}{$\mathrm{km}$} & \multicolumn{2}{|c|}{ Flow rate } & \multicolumn{2}{|c|}{ Capacity } & $\begin{array}{c}\text { Power plant } \\
\text { operating time } \\
\text { [days/year] }\end{array}$ & $\begin{array}{c}\text { Potential amount } \\
\text { of energy [MWh/ } \\
\text { year] }\end{array}$ \\
\cline { 3 - 7 } & & mean $\left[\mathrm{m}^{3} / \mathrm{s}\right]$ & design $\left[\mathrm{m}^{3} / \mathrm{s}\right]$ & theoretical [kW] & technical [kW] & 300 & 259.2 \\
\hline 1 & $0+450$ & 2.93 & 2.6 & 46.0 & 36.0 & 270 & 219.7 \\
\hline 2 & $8+180$ & 1.8 & 1.6 & 43.3 & 33.9 & 300 & 161.2 \\
\hline 3 & $13+380$ & 1.3 & 1.2 & 40.8 & 28.5 & 250 & 129.0 \\
\hline 4 & $18+230$ & 1.1 & 1.0 & 27.5 & 21.5 & 300 & 125.3 \\
\hline 5 & $29+060$ & 0.9 & 0.8 & 22.2 & 17.4 & 300 & 59.2 \\
\hline 6 & $33+860$ & 0.7 & 0.6 & 10.5 & 8.2 & & \\
\hline
\end{tabular}

According to planning documents, the documented technical capacity of the river Bystrzyca Północna is $0.14 \mathrm{MW}$. The theoretical energy resources of the river amount to $10 \mathrm{GWh}$, while $1.23 \mathrm{GWh}$ are technically possible to use [Stan... 2012]. The author's own calculations show that the energy generation capacity is lower (by about $20 \%$ ), whereas the analysis provides for limitations in the power plant operating time with regard to the environmental conditions. Such an approach seems reasonable in confrontation with the actual operation of small hydroelectric power plants already in operation on the river covered by the study. The operation of the power plant on Tchórzew weir was temporarily suspended at the request of farmers using grasslands along the river, since they were not able to make hay due to elevated water levels. The design documents as well as energy and economic analyses should consider such situations.

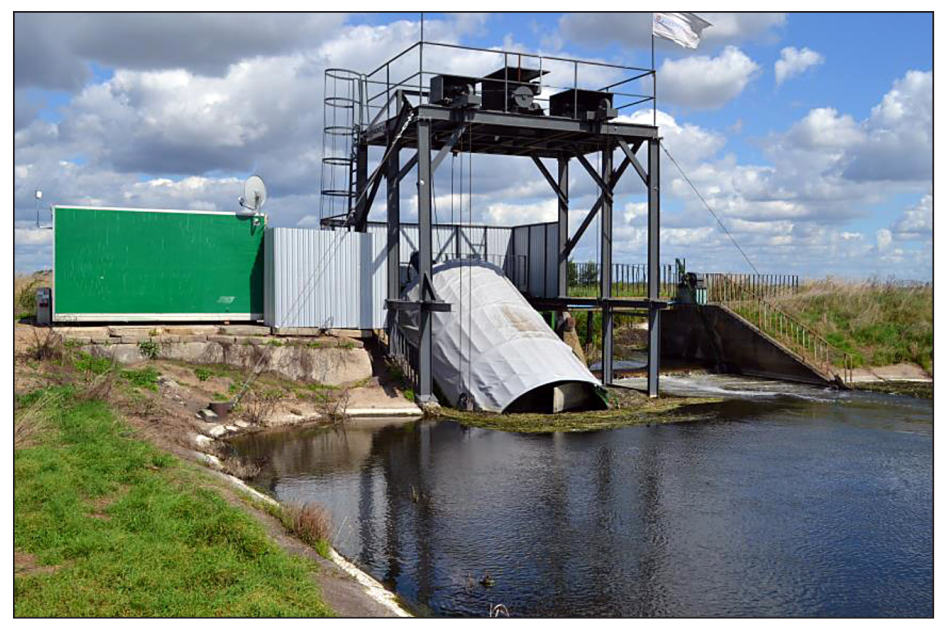

Figure 2. A view of the hydroelectric power plant erected in 2016 on the weir in Tchórzew (phot. A. Mazur)

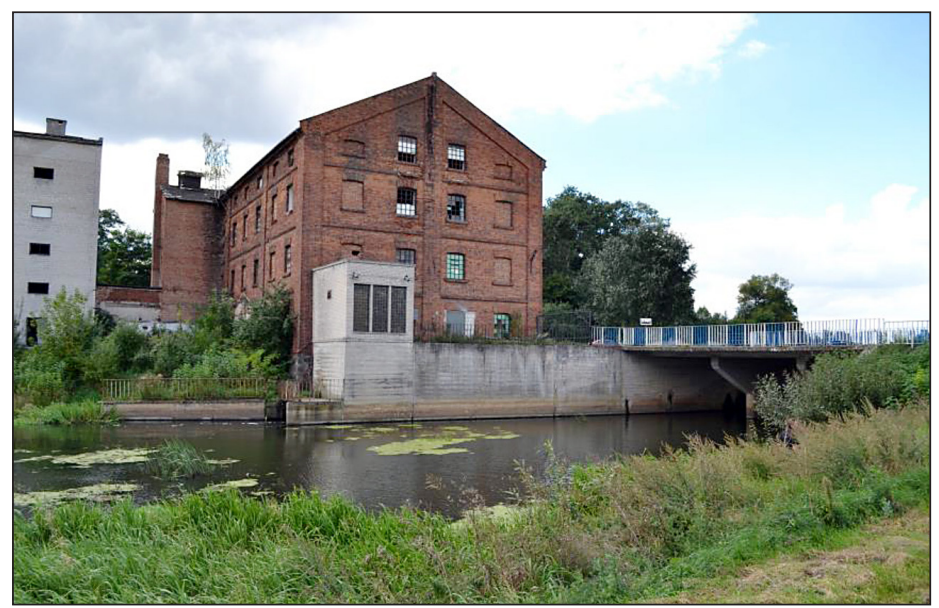

Figure 3. A view of the hydroelectric power plant erected on the weir attached to an old watermill in Borki (phot. A. Mazur) 


\section{ENVIRONMENTAL AND REGULATORY ASPECTS}

Hydroelectric power plants erected on the river can cause many adverse changes in its ecosystem. The major changes occur in the river itself and in its direct neighbourhood. The effect of hydroelectric power plants on the river ecosystem depends on their sizes and types [Sikora, Miller 2004]. Turbine types and accompanying equipment such as: dams, locks, weirs, trash-racks degrading rivers as wildlife corridors play an important role. The erection of barriers preventing free migration of hydrobionts would cut off the way to breeding grounds for migrating species, as a result preventing their reproduction [Jankowski 2004]. A tendency for retreating was observed among species associated with natural river channels and valleys, deprived of the possibility to dug holes in the slopes, and having their habitats in flowing waters, i.e. salmon, trout, as well as groups of reophile fish. Fish flowing through turbines mostly die [Chudy 2004, Jankowski 2004]. The reservoir in front of the dam is often a sedimentation tank containing pollutants carried by the river, so toxic waste containing large amounts of heavy metals can accumulate at the bottom. At the same time, such reservoirs are subject to eutrophication cause by constant influx and accumulation of nitrogen and phosphorus compounds [Antonowicz 2003].

The possibilities for the development of hydropower engineering are determined by both water and energy resources of rivers and regulatory framework. These limitations refer to excluding investments from protected areas or adapting the scale of projects to territorial and environmental conditions [Świtała 2007].

With reference to protected areas, as interpreted according to the Environmental Protection Act, it is not allowed to locate investments with possible considerable environmental effect within landscape parks and protected landscape areas pursuant to regulations approving respective forms of protection. The exclusion is also applicable to hydroelectric power plants located within the established protection limits where the completion of the project will breach the bans referred to in Art. 14 par. 2 of the Inland Fisheries Act of 18 April 1985 (Dz. U. (Journal of Laws) of 2009 No. 189 item 1471): "fishing or activities that are harmful for fish, and in particular intruding on breeding facilities, bottom of the reservoir and water plants, motor-boating sports and bathing are prohibited within protection limits".

The utilization of water resources in Poland is regulated by provisions of the Water Law [Ustawa... 2001]. Multiple amendments due to the implementation of European Union's regulations impaired the consistency and transparency of the act. The new Water Law raises many objections, among other things, due to the water use fees charged to energy companies. It is worth adding that hydroelectric power plants in other member states of the European Union must face similar problems. In Italy or France the fees for the use of water are not charged, but they do exist in Norway or Sweden.

An important element at the stage of planning a hydroelectric power plant is recognizing the aquatic environment (species of fish having their habitats in the specific river, are they migrating species), and then considering the scope of the project in the context of Art. 63 par. 1 and 2 of the Water Law of 18 July 2001 (Dz.U. of 2005 No. 239, item 2019, as amended), according to which:

Designing, building and maintaining water structures shall be based on the principle of sustainable development, and in particular preserving the waters in good condition and their characteristic biocenoses, the need for preserving the existing relief and biological relations in the aquatic environment and in wetlands.

Impounding structures should allow migration of fish if justified by the local environmental conditions.

The task of the-called fishways, that is, structures enabling the passage of water animals through impoundment elevation, is to reduce the rate of water flow to values corresponding to the possibility of overcoming the current by both fish living in the river and invertebrates.

The development of hydropower engineering is connected with the Framework Water Directive [Ramowa... 2000] under which the EU member states are required to reasonably use and protect the water resources according to the sustainable development policy.

An important regional document is Resolution No. XIII/197/07 of the Council of Lublin Region of 30 November 2007 concerning the adoption of the "Programme for protection and development of water resources in Lublin Region with respect to clearing the rivers for the needs of diadromus fish". It contains a list of barriers preventing migration that must be removed. The 
programme aims at restoring the former, historical migration routes of diadromus migratory fish within the area of Lublin Region. Its implementation refers to certain fragments of river catchments that, with regard to still preserved natural breeding areas and limited amount of baffles in the river channel, provide a real chance that after clearing they will become accessible to fish.

When choosing the location for hydroelectric power plants, the negative effect on protected objects in Nature 2000 areas within the range of the project must be also considered.

Regulations concerning the functions and location of hydroelectric power plants are contained in the Regulation of the Minister of Environment of 20 April 2007 on technical conditions to be fulfilled by hydrotechnical structures and their location [Rozporządzenie... 2007].

Regulations concerning renewable energy sources have an indirect effect on the construction of hydroelectric power plants. They determine project profitability expressed as its economic potential. For the purposes of this paper, the economic potential was not calculated with regard to the fact that dynamic changes in the systems supporting renewable energy enable a clear assessment of economic efficiency.

In addition, issues complicating the hydroelectric power plant investment process have been indicated: lack of a public list of impoundment structures owned by the State Treasury; unregulated legal status of real property; lack of effective regulations on making impoundment structures available for the purposes of hydropower engineering [Kryteria... 2005].

\section{CONCLUSIONS}

The decision on erecting a hydroelectric power plant, irrespective of its size, should be preceded by a thorough analysis of energy, economic and environmental effects. Even small hydroelectric power plants can change the hydrological conditions, the habitats for many species of fauna and flora and impair the possibility of using land adjacent to the watercourse. A negative influence on animate and inanimate elements of the environment can be greater than the ecological effect of renewable energy. The theoretical potential of hydroelectric power plants should be verified considering the local operating conditions. According to the analysis, the technical potential of small hydroelectric power plants on the river Bystrzyca Północna is about ca. $125.5 \mathrm{~kW}$. The complexity of Polish legislation having influence on the investment process may seem excessive but it makes it possible to avoid locating the project in a wrong place. Apart from evaluating the plant's location, it is also important to choose a technology keeping the environmental impact at the minimum level.

\section{REFERENCES}

1. Aktualizacja programu małej retencji dla województwa lubelskiego. Biuro Projektowo - Usługowe Wodnych Melioracji, Wodociągów i Kanalizacji „MELWOPROJEKT”Sp. z o.o. Warszawa, 2004.

2. Antonowicz A. 2003. Ekofundusz a mała energetyka wodna - za i przeciw. Czysta Energia, nr 3, 14.

3. Bełej M., Ostrowska A. 2007. Analiza efektywności inwestycji w nieruchomości z uwzględnieniem efektu ekologicznego na przykładzie małej elektrowni wodnej. Acta Scientarum Polonorum, Administratio Locorum 6 (2), 35-53.

4. Chudy Ł. 2004. Małe elektrownie wodne w środowisku i gospodarce. Gospodarka Wodna, nr 7, 272-277.

5. Gajda I. 2006. Czy zasoby hydroenergetyczne Polski są w stanie zapewniać bezpieczeństwo energetyczne? Przegląd Geologiczny, vol. 54, nr 8, 660-667.

6. Jankowski W. 2004. Negatywny wpływ zabudowy hydrotechnicznej rzek na przyrodę. Wydawnictwo Politechniki Wrocławskiej.

7. Jarosiewicz A., Toczko K. 2006. Hydroenergia droga do poprawy stanu jakości środowiska przyrodniczego. Słupskie Prace Biologiczne nr 3, 13-22.

8. Kamiński J., Wójcik-Jackowski S. 2011. Uwarunkowania środowiskowo-prawne rozwoju energetyki wodnej w południowo-wschodniej Polsce. Polityka Energetyczna, t. 14 (1), 17-27.

9. Karolewski B., Ligocki P. 2004. Wyznaczanie parametrów małej elektrowni wodnej. Prace Naukowe Instytutu Maszyn, Napędów i Pomiarów Elektrycznych Politechniki Wrocławskiej, 56.

10. Koch F. H. 2002. Hydropower - the politics of water and energy: Introduction and overview. Energy Policy, nr 30, 1207-1213.

11. Kryteria opiniowania przedsięwzięć w zakresie małej energetyki wodnej. 2005. RZGW w Krakowie (www.krakow.rzgw.gov.pl).

12. Kułagowski W. 2001. Hydroenergetyka w Polsce - stan obecny, perspektywy rozwoju. Gospodarka Wodna, nr 3, 119-123. 
13. Mikulski Z. 1998. Gospodarka wodna. PWN Warszawa.

14. Pichla A., Jakimiuk S. 2014. Budowle wodne i melioracyjne Lubelszczyzny. Infrastruktura i Ekologia Terenów Wiejskich, II, 1, 173-193.

15. Program ochrony przed suszą w województwie lubelskim. Wojewódzki Zarząd Melioracji i Urządzeń Wodnych w Lublinie. PPHU „ADEKO” s.c. Kraków, 2008.

16. Ramowa Dyrektywa Wodna (RDW), Dyrektywa 2000/60/WE Parlamentu Europejskiego i Rady z dnia 23 października 2000 roku ustanawiająca ramy wspólnotowego działania $\mathrm{w}$ dziedzinie polityki wodnej (Dz. Urz. WE L 327 z 22.12.2000 roku, str. 1; Dz. Urz. UE Polskie wydanie specjalne, rozdz. 15, t. 5, str. 275 z późn. zm.).

17. Rozporzadzenie Ministra Środowiska z dnia 20 kwietnia 2007 roku w sprawie warunków technicznych, jakim powinny odpowiadać budowle hydrotechniczne i ich usytuowanie (Dz. U. Nr 86, poz. 579).
18. Sikora B., Miller M. 2004. Wpływ elektrowni wodnych na ekosystem rzeczny. Wyd.: Kukiełka L. (red.). Wykorzystanie niekonwencjonalnych źródeł energii. Słupsk.

19. Stan i perspektywy rozwoju hydroenergetyki w województwie lubelskim. Biuro Planowania Przestrzennego w Lublinie, 2012.

20. Świtała F. 2007. Stan ekosystemu zlewni rzeki Huczwa a możliwości energetycznego jej wykorzystania. Polityka Energetyczna, t. 10, z. 2., 557-567.

21. Ustawa $z$ dnia 18 lipca 2001 r. Prawo wodne (Dz. U. z 2012 r. Nr 0, poz. 145 z późn. zm.).

22. Wheaton-Green K. 2016. What would you choose? Rolls Royce or Peugeot? The Landsman, 5/6, 15.

23. Wilgat T. 1998. Wody Lubelszczyzny. Środowisko Przyrodnicze Lubelszczyzny. LTN, Lublin.

24. Witkowski K., Filipowski A., Gromiec M. 2001. Obliczanie przepływu nienaruszalnego. IMGW Warszawa.

25. www.ure.pl

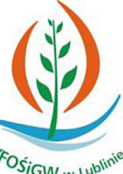

Pracę dofinansowano ze środków Wojewódzkiego Funduszu Ochrony Środowiska i Gospodarki Wodnej w Lublinie. 